\title{
地すべり地内に打汗地下水区分の一手法 \\ On Some Proposal Methods for Division of Ground Water in Landslide Areas
}

長 溝 忍*

Shinobu Nagamtzo

\begin{abstract}
Investigation of water quality of ground water in landslide areas is sometimes used for design of drainage works for landslide control. Considering a selection of elements of water quality and division of ground water, $\mathrm{Ca}^{++}, \mathrm{Mg}^{++}$and alkalinity are indispensable and division of ground water can be done by using a correlation between $\mathrm{Ca}^{++}+\mathrm{Mg}^{++}$and alkalinity. It is found that water quality in landslide areas is not peculiar and have a resemblance to the water distributing generally over the earth.
\end{abstract}

\section{まえがき}

地すべり活動炕最も大きな影響を与兄るものが地下水 であることは，地すべりの実態統計1からも，また地す ベりの発生誘因が図一隹すように, 自然的な誘因によ るものがほとんどであり，この誘因中，水によるものが 図-2から豪雨時, 長期間の降水, 融雪時之計 $81 \%$ 飞及 んでいることから裏付けられる。

地すべり対策工法もこれを受けて図ー3に示すよらに, 地表水路工, 水拔ボーリング工, 集水井工と, 地表水, 地下水の処理に関するものが多い。したがって, これ等 の地表, 地下水の排除の工法の選択, 及びその効果を高 めるためには, 事前に地下水調查を行ない, 地下水の区 分及び地下水系の区分が必要となる。この地下水調䍒に よる地下水の診断に水質分析の結果が用いられている。 地下水の水質は地下水がそれまでに接触して来た地質的 な環境, 履歴を反映したものであり, 水質の変動は地下 水の流動状況に関して有力な情報を提供するものと考兄 られるからである。

地すべり対策工法の地下水排除工法の目的は, 高い水 臣をもった滞水層の水圧を下げることによって，すべり 面に働く間隙水圧の減少を計ることである。本文はこの 地すべり活動の誘因となる滞水層及び滞水層へ流入して いる地下水系の区分を水の硬度によって試みたもので, 地すべり地の地下水診断の一手法として発展させること ができないものかと期待するものである。

\section{1. 一般的な陸水の水質}

地すべり地の陸水の水質についで述べる前に一般的な

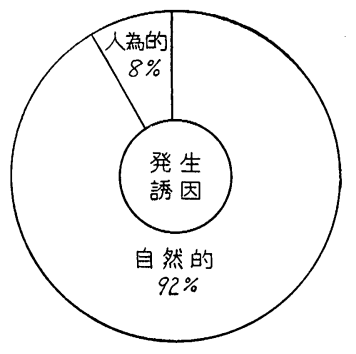

図-1地すべり発生誘因1

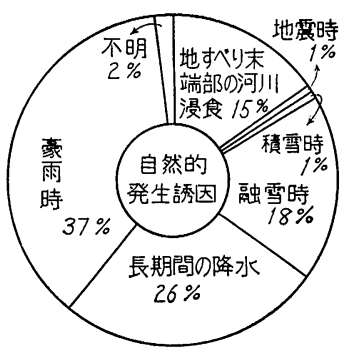

図-2 地すべり発生誘因 (自然的発生誘因) 1

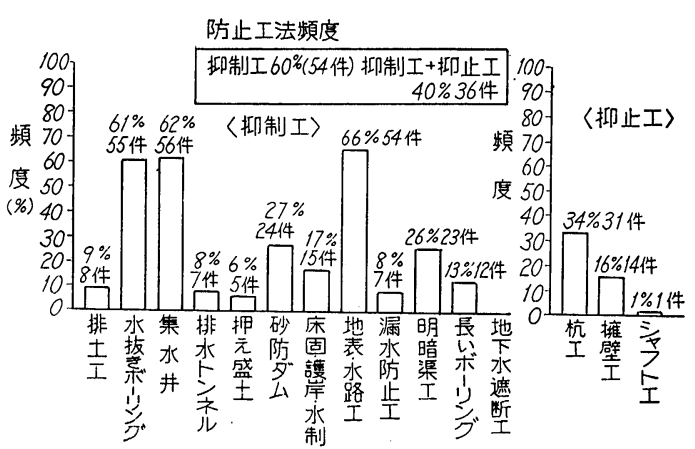

図-3 地すべり対策工 ${ }^{1}$

陸水の水質組成について述べる。

地殼を構成する鉱物で, 最も量が多いのは珪酸塩鉱物 であり,このらち, 地下水と反応しやすいものは長石類 である。

$$
\begin{aligned}
& 2 \mathrm{NaAlSiO}_{3} \mathrm{O}_{8}+2 \mathrm{CO}_{2}+3 \mathrm{HCO}_{3} \rightarrow \\
& 2 \mathrm{Na}^{+}+2 \mathrm{HCO}_{3}{ }^{-}+4 \mathrm{SiO}_{2}+\mathrm{Al}_{2} \mathrm{SiO}_{5}(\mathrm{OH})_{4}
\end{aligned}
$$

珪酸程鉱物よりは量的に少ないが, 岩石中に普遍的に 含まれ，かつ，水の反応に弱いのが炭酸塩鉱物であり， 代表的な鉱物は，炭酸カルシウム(方解石), 炭酸マグ ネシウム（苦灰石）である。 
$\mathrm{CaCO}_{3}+\mathrm{CO}_{2}+\mathrm{H}_{2} \mathrm{O} \rightarrow \mathrm{Ca}^{2+}+2 \mathrm{HCO}_{3}^{-}$

$\mathrm{MgCO}_{3}+\mathrm{CO}_{2}+\mathrm{H}_{2} \mathrm{O} \rightarrow \mathrm{Mg}^{2+}+2 \mathrm{HCO}_{3}^{-}$

水が岩石と反応（風化）しながら流下するにつれて, $\mathrm{Na}^{+}, \mathrm{Ca}^{2+}, \mathrm{Mg}^{2+}, \mathrm{HCO}_{3}$ - 等の溶存成分は増加する。 表-1に淡水性地下水の水質の変質方向を示した。

また，溶けやすさの一般的傾向を示すと

$\mathrm{SiO}_{2}<\Sigma$ 陽イオン, $\mathrm{Na}>\mathrm{K}$

$\mathrm{Ca}>\mathrm{Mg}, \mathrm{Mg}+\mathrm{Ca}>\mathrm{Na}+\mathrm{K}$

でるあ。

以上のことから一般陸水の性質は炭酸水素塩を主とす る地下水であること, 換言すれば一時硬水 ( $\mathrm{Ca}, \mathrm{Mg}$ が 炭酸水素塩となって溶けている状態）を呈していること がらなずける。

一時硬水 $\mathrm{Ca}\left(\mathrm{HCO}_{3}\right) \rightarrow \mathrm{CaCO}_{3}+\mathrm{H}_{2} \mathrm{O}$

$$
\mathrm{Mg}\left(\mathrm{HCO}_{3}\right) \rightarrow \mathrm{MgCO}_{3}+\mathrm{H}_{2} \mathrm{O}
$$

〈タイプ分類〉

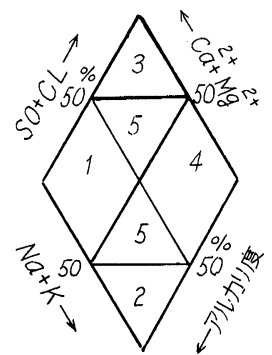

(1) Carbonate hardness

重炭酸カルシウム，マグネシウムを主成分とする水

(2) Carbonate Alkali

重炭酸ナトリウム，カリを主成分とする水

(3) Non Cabonate hardness

塩化土類, 硫酸土類を主成分とする水

(4) Non Cabonate Alkali

塩化アルカリ，硫酸アルカリを主成分とする水

（5） 1 と 2 の区分に属する中間的なるの

〈作図法〉

(1) $\left\{\begin{array}{l}\mathrm{HCO}_{3}^{-}(\%)=\frac{\mathrm{HCO}_{3}}{\mathrm{HCO}_{3}^{-}+\mathrm{Cl}^{-}+\mathrm{SO}_{4}^{2}} \times 100 \\ \mathrm{Cl}^{-}+\mathrm{SO}_{4}^{2-}(\%)=100-\mathrm{HCO}_{3}^{-}\end{array}\right.$

(2) $\left\{\begin{array}{l}\mathrm{Ca}^{2+}+\mathrm{Mg}^{2+}(\%)=\frac{\mathrm{Ca}^{2+}+\mathrm{Mg}^{2+}}{\mathrm{Ca}^{2+}+\mathrm{Mg}^{2+}+\mathrm{Na}+\mathrm{K}} \times 100 \\ \mathrm{Na}^{+}+\mathrm{K}^{+}(\%)=100-\left(\mathrm{Ca}^{2+}+\mathrm{Mg}^{2+}\right)\end{array}\right.$

〈タイプ分類に対する一般的判定〉

(1) 炭酸カルシウム $\left(\mathrm{Ca}\left(\mathrm{HCO}_{3}\right)\right.$ タイプ: $\mathrm{Ca}\left(\mathrm{HCO}_{3}\right)_{2}, \mathrm{Mg}$ $\left(\mathrm{HCO}_{3}\right)_{2}$ の組成で我が国の一般的地下水のタイブ .

(2) 炭酸ナトリウム $\mathrm{NaHCO}_{3}$ タ、イプ: 停滞的な環境にある地 下水のタイプ

(3) 非炭酸カルシウム $\mathrm{CaCl}_{2} . \mathrm{CaSO}_{4}$ タイプ: 温泉水, 鉱泉, 化石水などがこのタイプで一般の地下水とは異なる傾向があ る。

（4）非炭酸ナトリウム $\mathrm{NaCl}$ タイプ: $\mathrm{Nacl}$ の水質組成で, 海水 や海水に污染された地下水, 温泉水がこのタイプ。

（4）中間タイブ：0〜4の中間に位するもので, 河川水, 伏流 水及び自由水のタイブ

図-4 Keydiagram 説明図
表-1 淡水性地下水の変質方向

\begin{tabular}{|c|c|c|}
\hline 成 & 分 & 地下水の流動についての增減 \\
\hline & & + \\
\hline & & - \\
\hline & & - \\
\hline & & + \\
\hline & & - \\
\hline & & - \\
\hline & & 不 定 \\
\hline & & + \\
\hline & $\mathrm{Fe}^{3+}$ & + \\
\hline & & + \\
\hline & & + \\
\hline & & - \\
\hline & & + \\
\hline & & - \\
\hline & & 不 定 \\
\hline
\end{tabular}

（参考）永久硬水 : $\mathrm{Ca}, \mathrm{Mg}$ が硫酸塩や塩化物となって 溶けている。 $\mathrm{CaSO}_{4}$

一時硬水であることは図-4（キーダイアグラム）での 分類判定(1)のタイプが我が国の一般的な地下水のタイプ であることと一致する。

\section{2. 分析結果の解析方法}

次に一般に使用されている，キーダイアグラム（Key-
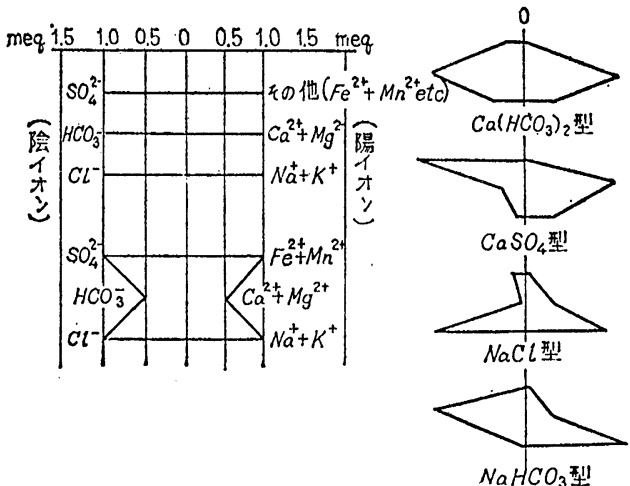

図-5 Hexadiagram の模式図と水質型の分類

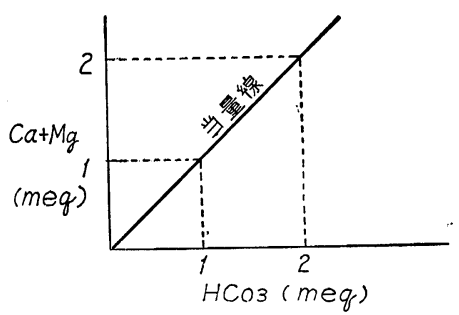

〈タイブ分類〉

1) $\mathrm{Ca}+\mathrm{Mg}<\mathrm{HCO}_{3}$ (当量線上側)：重炭酸丁ルカリ系

2）当量線上: 重炭酸硬度系

3) $\mathrm{Ca}+\mathrm{Mg}>\mathrm{HCO}_{3}$ (当量線下側): 硫酸硬度系

〈タイフ分類に対する判定 $\left.{ }^{2}\right\rangle$

1）河川ょりの供給を受けない滐い地下水で，河川に無関係か，河川か らの供給を受けたとしても相当離れた地点

3）浅い地下水, 河川水

図-6 
地すべり Vol. 15, No.4 (1979)

表-2 ppm より eqm の換算係数

\begin{tabular}{|c|c|}
\hline 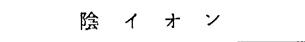 & 陽 イオン \\
\hline 重峞酸 $\underset{\left(\mathrm{HCO}_{3}{ }^{*}\right) \cdots \cdots .0 .0164}{ }$ & 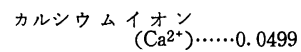 \\
\hline 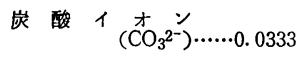 & $\begin{array}{l}\text { マグネシウム } \\
\quad\left(\mathrm{Mg}^{2+}\right) \cdots \cdots \\
\end{array}$ \\
\hline 硫酸 $1 \underset{\left(\mathrm{SO}_{4} 2^{2-}\right) \cdots \cdots . .0 .0208}{2}$ & ナトリウム $\underset{\left(\mathrm{Na}^{+}\right) \cdots \cdots .0 .0435}{オ}$ \\
\hline 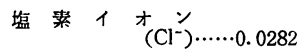 & カリウムイ $\underset{\left(\mathrm{K}^{+}\right) \cdots \cdots . .0 .0256}{\pi}$ \\
\hline 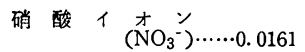 & 第 1 鉄 $1 \underset{\left(\mathrm{Fs}^{2}\right) \cdots \cdots .0 .0358}{\pi}$ \\
\hline 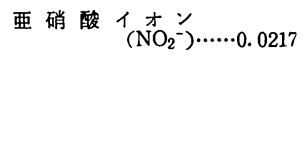 & 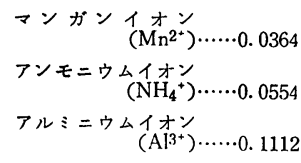 \\
\hline
\end{tabular}

diagram) とへキサダイアグラム (Hexad iagram) によ る解析方法及び硬度 $(\mathrm{Ca}+\mathrm{Mg})-\mathrm{HCO}_{3}$ 相関図について 図-4〜6に示す。

図の説明のよ5に，キーダイアグラム（図-4）は水質 成分の存在比を示すので量的関係が不明であるのに対し て, ヘキサダイアグラム (図-5) は各成分の存在量 (eqm: ミリグラム当量, 表-2に ppm より eqm の換算係数を 示す）の多少を示すので理解しやすく, 特長として

1）作図が容易

ロ）図形による水質組成の判定が簡便

八）同一囝形の追跡により，溶存成分量の消長から水 塊の区分が可能

が上げられ，キーダイアグラムよりへキサダイアグラム の方がより水系区分には適しているものと思われる。

次に硬度 $-\mathrm{HCO}_{3}$ 相関図（図-6）について説明する。こ の相関図は北野の理諭2)によるもので，岩 石同化の予知と共に同一水系では公配45度 の直線の上に載ることと地域的に集中する

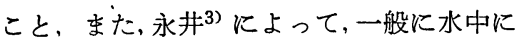
扣ける主成分は陰イオンでは $\mathrm{HCO}_{3}{ }^{-}, \mathrm{Cl}^{-}$, $\mathrm{SO}_{4}{ }^{2-}$, 陽イオンでは $\mathrm{Ca}^{2+}, \mathrm{Mg}^{2+}, \mathrm{Na}^{+}, \mathrm{K}^{+}$ であり，陰イオンの構成を見ると $\mathrm{HCO}_{3}$ が空気中の $\mathrm{CO}_{2}$ および炭酸塩, 有機物の 分解で生ずる $\mathrm{CO}_{2}$ の溶解により量的に最 多量を占め, 陽イオンでは火山岩, 変成岩 などからの溶出は $\mathrm{Ca}$-長石の方が $\mathrm{Na}$-長石 より溶解度が大きいこと, また炭酸塩の場 合には $\mathrm{Ca}, \mathrm{Mg}$ が主成分であるため, $\mathrm{Ca}+$ $\mathrm{Mg}$ が $\mathrm{Na}+\mathrm{K}$ よりはるかに多い（溶けや すさ: $\mathrm{Ca}+\mathrm{Mg}>\mathrm{Na}+\mathrm{K})$. 浅い地下水, 河 川水では $\mathrm{HCO}_{3}$ に対して $\mathrm{SO}_{4}, \mathrm{Cl}$ の比率 が比較的高いために $\mathrm{HCO}_{3}$ と $\mathrm{Ca}+\mathrm{Mg}$ の 関係をみると、ほとんどが $\mathrm{HCO}_{3}<\mathrm{Ca}+\mathrm{Mg}$ の関係にあり、一方深い地下水では酸素の 供給が欠乏するため, 還元状態となり $\mathrm{SO}_{4}{ }^{2-}$ が減少 $\left(\mathrm{SO}_{4}{ }^{2-}\right.$ はしだいに還元されて $\mathrm{H}_{2} \mathrm{~S}$
となる), $\mathrm{HCO}_{3}$ - が増大するが陽イオンでは変化が少な いため，この関係は逆転し，河川よりの供給を受けない 深い地下水は，ほとんどが $\mathrm{HCO}_{3}{ }^{-}>\mathrm{Ca}^{2+}+\mathrm{Mg}^{2+}$ であ る。したがってこの関係を用いると河川からの地下水の 供給を裏付けることが可能であると論じて図-6 の説 明 のように地下水の区分を行なっている。

一般陸水が二時硬水を呈していることから，地下水 系, 地下水区分に当っては硬度 $-\mathrm{HCO}_{3}$ 相関図が適して いると思われる。

\section{3. 地すべり地内の地下水の水質及び水系区分}

一般に地すべり地には通常の斜面に比較して多量の地 下水が分布していることはよく知られている，図-7に地 すべり地の水下水分布の模式図を示す。

渡4) は地すべり地陸水を表-3 のように区分している。 水質特徴としては，浅層地下水は降水の水質と同じ，深 層地下水は鉱泉質で基盤面地下水は深層地下水に似てい ると述べ，牧，富田 ${ }^{5)}$ は地すべり地带陸水の最も大きな 特徵は重炭酸塩を主としていると報告しており，また有 泉6) は第三紀の地すべりでは $\mathrm{CaSO}_{4}, \mathrm{MgSO}_{4}$ の濃度が 高く，第三紀以外ではアルカリ度が高いと述べている。 松崎, 飯田 ${ }^{7)}$ は統計的手法を用い, $\mathrm{Ca}+\mathrm{Mg}$ と $\mathrm{SO}_{4}$ 及 び $\mathrm{HCO}_{3}$ との相関性の高い事夷に, 吉岡, 古谷 ${ }^{8}$ は第三 紀層, 破砕帯地すべりとも一般に溶存成分量は表流水, 涌水，ボーリング孔の水の順に多くなっていること，陽 イオンとして $\mathrm{Ca}^{2+}$, 陰イオンとして $\mathrm{HCO}_{3}{ }^{-}$が卓越して いることを指摘している。また，杉崎，柴田 ${ }^{9)}$ にって

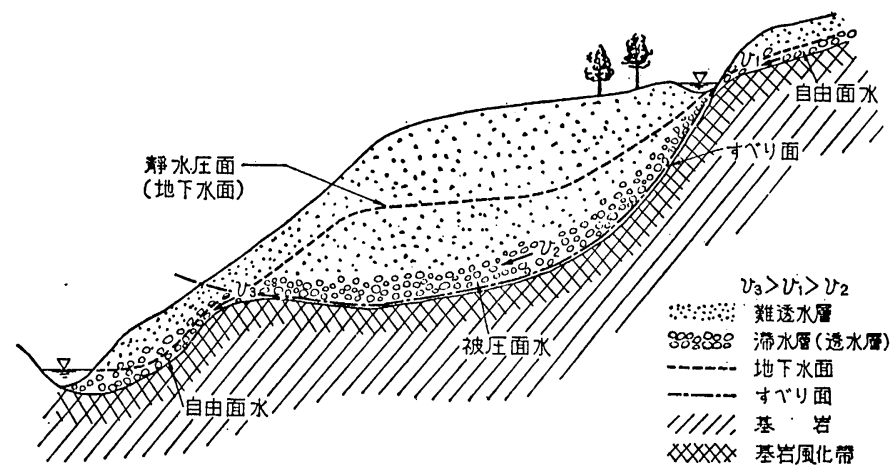

図-7 地すべり地の地下水分布

表-3 地下水区分

\begin{tabular}{|c|c|c|c|}
\hline 地下水区分 & 滞 水 場 所 & 質 & 地すべりへ及ぼす影嚮 \\
\hline 浅層地下水 & 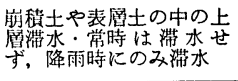 & $\begin{array}{l}\text { 降水の水質と } \\
\text { まったく同兒 }\end{array}$ & 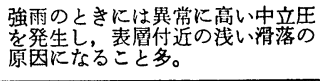 \\
\hline 基盤面地下水 & 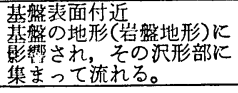 & $\begin{array}{l}\text { 深䚄水と似た } \\
\text { 水 }\end{array}$ & 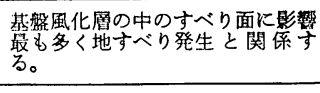 \\
\hline 深層地下水 & $\begin{array}{l}\text { 断層やそれに治った破砕 } \\
\text { 部 }\end{array}$ & 鉱泉㭚 & $\begin{array}{l}\text { 地すべりの誘因となることは少な } \\
\text { いが, 誘因となった場合比較的大 } \\
\text { 規模な地すへりを起こす。 }\end{array}$ \\
\hline
\end{tabular}


地下水の化学成分の流動に伴ら変化について, 溶出作用 は地層との接触時間が長いはど, 溶出によって溶存化学 成分が増加する。(1)全陽イオン量の増加（各イオン間の 相互の比率は考えない) (2) $\mathrm{HCO}_{3}$ - の増加。したがって $\left(\mathrm{HCO}_{3}{ }^{-}\right.$/全陰イオン) の增加, $\mathrm{Cl}$-は地中に起源がない 場合が一般であるから（Cl-/全陰イオン）の減少が見ら れると報告している。

以上の諸報告等から, 地すべり地内の地下水の一般的 性質から，地下水区分及び水系区分に当っては,

(1) 溶存割合,

（2）溶存成分量

について把えることができて, 陰イオンでは $\mathrm{HCO}_{3}{ }^{-}$が, 陽イオンでは $\mathrm{Ca}^{2+}, \mathrm{Mg}^{2+}$ が指標になる。

以上の要件を満たす解析方法は 2 節の解析方法 (図-6) で述べた硬度 $-\mathrm{HCO}_{3}$ 相関図が適していることになる。

これは，陸水の一般的な性質を見る場合と同じことに なる。すなわち, 溶存成分的には地すべり地内の地下水 と一般陸水の性質との間には差がないことになる（各々 の地すべり陸水には各々水質的特徽が見られるが6)。

硬度- $\mathrm{HCO}_{3}$ 相関図を適用するに当り, 地表流水と地 下水との区分の目安を 表-4 より河川水中で最も溶存量 の多い関東地方の值から,一応 0.7 ミリ゙ラム当量 (eqm) の值を使らこととして, $0.7 \mathrm{meq}$ 以上で地下水の 浅・深層の区分を行ならこととした。また，地下水の区 分については前述の渡による区分を相関図上に図-8のよ らに当てはめて考察することにした。

\section{1 硬度 $-\mathrm{HCO}_{3}$ 相関図の適用例}

筆者は徳島県江畠地すべり（破砕带地すべり） ${ }^{10)}$ に拉

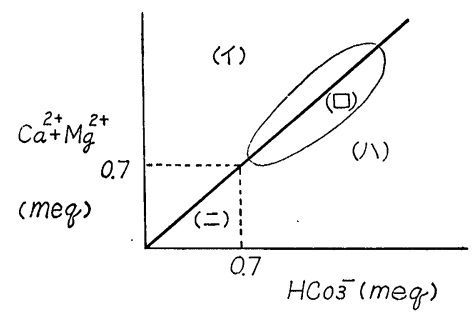

（1）浅層地下水 （口）基盤面地下水

図-8 地下水区分

表-4 河川水に扣ける $\mathrm{HCO}_{3}^{-}$と $\mathrm{Ca}^{2+}+\mathrm{Mg}^{2+}$ の関係 ${ }^{3}$

\begin{tabular}{|c|c|c|c|c|c|}
\hline 地 & 域 & 河 & 川 数 & $\begin{array}{l}\mathrm{HCO}_{3}{ }^{2} \\
(\mathrm{eqm})\end{array}$ & $\begin{array}{c}\mathrm{Ca}^{2^{+}}+\mathrm{Mg}^{2^{+}} \\
(\mathrm{eqm})\end{array}$ \\
\hline \multicolumn{2}{|c|}{ 北海道地方 } & 22 & 河川平均 & 0.55 & 0.60 \\
\hline 東 北 & $"$ & 35 & " & 0.33 & 0.54 \\
\hline 関 東 & " & 11 & " & 0.69 & 0.87 \\
\hline 中 部 & " & 42 & " & 0.49 & 0.58 \\
\hline 近 畿 & " & 28 & " & 0.45 & 0.49 \\
\hline 中 国 & " & 25 & $"$ & 0.45 & 0.42 \\
\hline 四 国 & $"$ & 19 & $"$ & 0.61 & 0.65 \\
\hline 九 州 & " & 43 & $"$ & 0.67 & 0.72 \\
\hline 全 国 & & 225 & " & 0.51 & 0.60 \\
\hline
\end{tabular}

いて硬度 $-\mathrm{HCO}_{3}$ 相関図を適用し, 溶存成分量から地下 水を図-9 に示すよらに区分し，地すべり地を涵養して いる地下水は主として混合地下水であることを報告し た。また,狛, 横田 ${ }^{11)}$ は第三系地すべり地で図-10に示す 区分（三角グラフとキーダィアグラムを倠用）より $\mathrm{Ca}+$

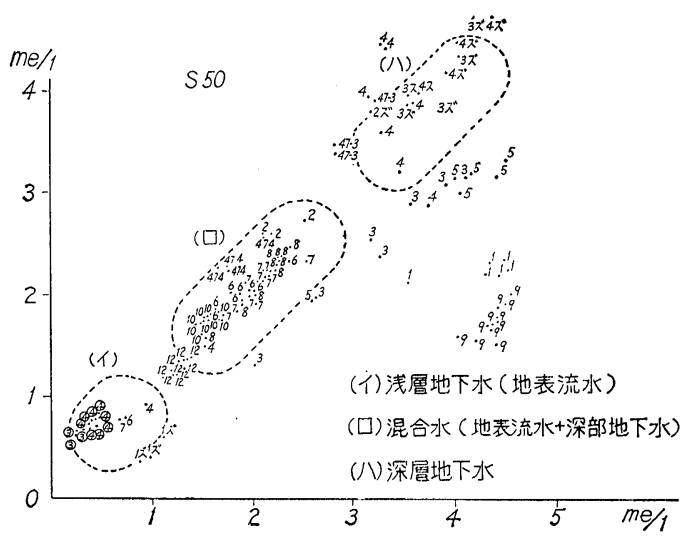

医-910
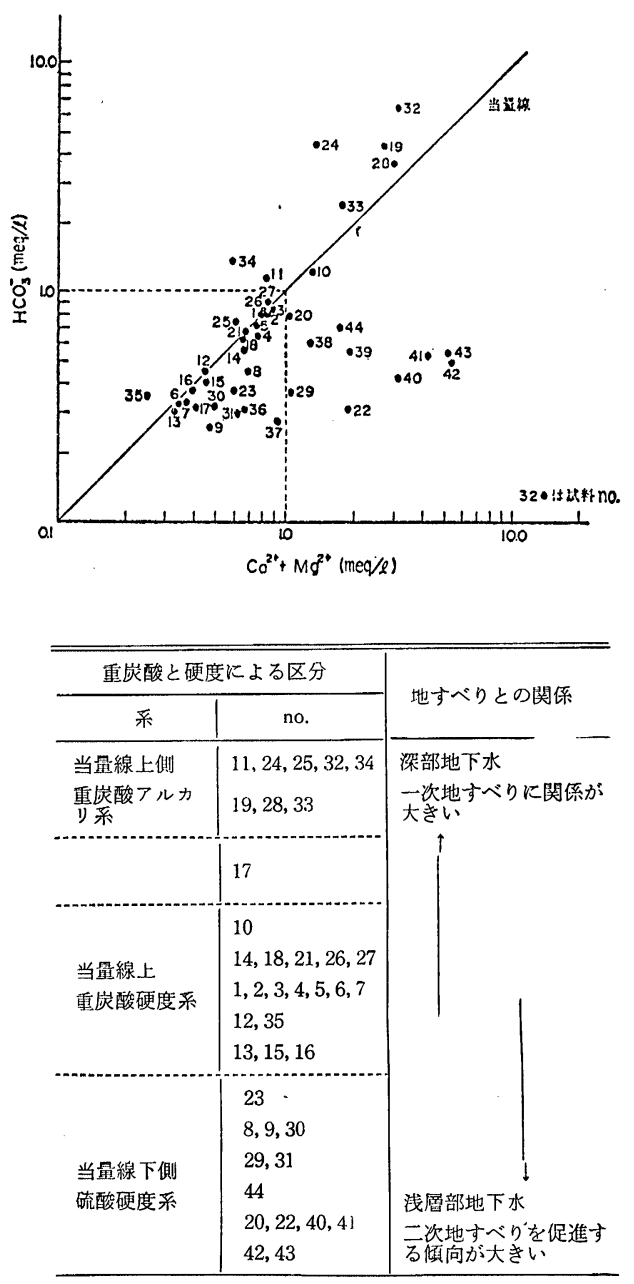

図-10 11 
$\mathrm{Mg}>\mathrm{HCO}_{3}$ の地下水は二次的な（崩壊層）地すべりを促 ᄂ, $\mathrm{Ca}+\mathrm{Mg}<\mathrm{HCO}_{3}$ の地下水は一次的な（構造性）地 すべりを促す役割をもっていると考察している。

江鼻地すべりでは同一地下水系での溶存成分量よりの 地下水区分の例であり，狛，横田の例は溶存成分量と領 域によるところの地下水区分である。

\section{2 地すべり地内の地下水の特徵について}

一般に地すべり地内の地下水が異常であると言われて いるので，有泉6)によって報告された全国の地すべりに 6 力所の地すべりを加えて, 眓-11 に示した。これと比 較するために鈴木 ${ }^{122}$ とよって報告されている全国の工業 用水に使用されている地下水を図-12 に示した。両者の 図からは特徽的なものは把劣ることができないし，一般 的な陸水の水質で述べた一般の陸水となんら变るところ はないよらに見られる。ただ地すべり地内の地下水の方 が溶存成分量の多いものが多いよらに見られる。

次に地下水の区分に目を移すと, 地すべり地内の地下 水の大半が，溶存成分量 $0.7 \mathrm{meq}$ 以下, $\mathrm{Ca}+\mathrm{Mg}>\mathrm{HCO}_{3}$ の区分に入るよらであり，これから考察するに，地すべ り地の涵荃水あるいは供給水は表流水かまたは浅層の地 下水が多いといらことになる。

\section{むすび}

地すべり地陸水の水質的特徵については報告がなされ

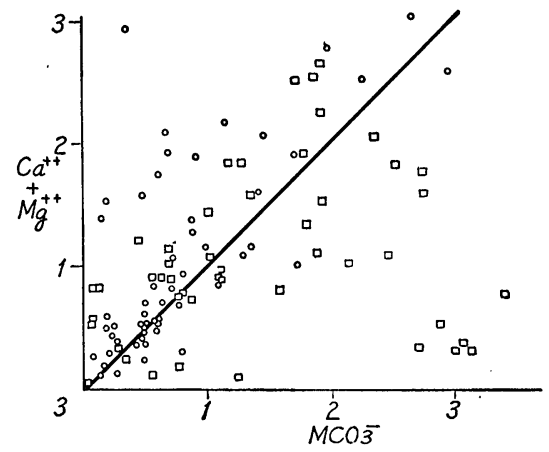

図-11 全国地すべり地陸水

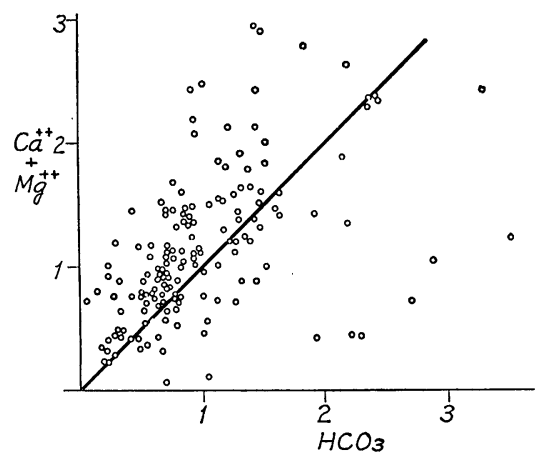

ているが，一般の陸水の水質についてあまり示されてい ないので，一般の陸水の水質を取り上げて，その解析方 法を述べて, 地すべり地内の地下水について述べた。

そして

(1) 地すべり地陸水の地下水区分に硬度 $-\mathrm{HCO}_{3}$ 相関 図が適している。

(2) 一般陸水との間に特に異なった点は見られない

(3) 地すべり地涵養水は浅層あるいは地表流水 であることを述べた。が，適用例が少ないため，今後， または，今までの地すべり地陸水の水質分析結果を見直 して，その適用性を把える必要がある。また，統計的手 法により，より一般性を持たせる必要がある。硬度一 $\mathrm{HCO}_{3}$ については松崎, 飯田 ${ }^{7)}$ により, へキサダイアグ ラムについては千葉 ${ }^{13)}$ とよる例がある。終りに当って宮 崎他 ${ }^{14}$ によって, 電導度 $-\mathrm{HCO}_{3}$ の関係から一般河川水 と地すべり周辺部の地下水との間に相異のあることが報 告されているので付け加えておく。

\section{参考文献}

1）地すべり実態統計（その 2）：土木研究所資料1121号，建設 省土木研究所砂防部地すべり研究室 (昭 51.2)

2）北野 康, 加藤喜久雄, 金森 悟, 金森暢子, 吉岡龍馬 : 水 質調查に上る岩石崩壊の予知の可能性，京都防多研，年報第10 号 A. p. 555 p. 587 (昭 42.3)

3）永井 茂：水質による地下水水采の解明，工業用水第114号 （昭 43.3）p.66 p. 75

4）渡 正亮：地すべり調查と対策講座 I 地すべり地の地下水 とその調查，全国地すべり対策協議会

5）牧隆正, 富田利保：松久山地すべり地帯陸水の水質的特性 について,「地すべり」Vol. 1, No. 3 (昭 40.3) p. 1 p.7

6）有泉 昌：地すべり地带陸水の水質について, 土木研究所報 告（昭 39.3） p. 1 p. 14

7）松崎 健, 即田修：地すべり地带の水質とその統計的分析 そついて「地すべり」Vol. 12 No.2（昭 50. 8）p. 19〜p. 27

8）吉岡龍馬, 古谷尊彦：地質環境のことなる地すべり地の水質 特性 京都防災研 年報第16号 B（昭 48.4）p 127 p. 139

9）杉崎隆一, 柴田 賢: 地下水の地球化学的研究（第 2 部)「地 質学雑誌」Vol. 67 No. 791 (昭 46.8） p. 427 p. 439

10）江香地すべり調查報告書：士木研究所資料第1203号，建設省 土木研究所 (昭 52.3)

11）狛 武，僙田節哉：第三紀地すべり地带に扰ける水質の特徵 地質調查所月報（第22巻 6 号）p. 13 p. 25

12）鈴木静夫：本邦地下水の化学成分の分布特性, 水処理技術 Vol. 7, No. 10, (昭 41) p. 1 p. 9

13）千葉 ヒ：水質分析による地すべり調查事例 第12回治山研 究発表会論文集, 治山研究会（昭 48.9） p. 296 p. 302

14）宮崎敏孝, 畔柳 健, 堀内照夫：水質調查による風化帯の推 定法について(II)－電尊度と溶出イオン量について一昭52年度 砂防学会研究発表会概要集 p. $10 \sim$ p. 11

（原稿受理日 昭和53年 9 月 30 日）

図-12 全国工業用水（地下水） 
地すべり斜面の安定解析と原位置大型供試体の長期クリープ試験

「地すべり」Vol. 15, No.4（通巻 第56号）1979年（昭和54年）3月

福本 安正, 寺川 俊浩, 小宮 利彦

地すべり斜面の安定解析に適合する土塊のせん断強さを求めるため, 地すべりが多発する冬期から春にかけて地 すべり斜面において原位置大型供試体の長期クリープ試験を特こなった。

その結果, 上限降伏值以上の応力を与えるならばせん断破壊すること, 上限降伏值は室内試験のせん断強さの $1 / 3$ よりも小さく，ほぼ残留強さと同值であることが明らかになっだ。クリープ性の地すべり斜面の安定解析には上限 降伏值がよく適合する。

地すべり斜面の地形解析による地すべりの判読と危険度判定

「地すべり」Vol. 15, No.4 (通巻 第56号) 1979年（昭和54年）3月

吉松 弘行, 坂元 靖秀

地すべりは，その構成土塊の性質に応した地形的特改を有しており，その発生箇所む異なることが知られている。 したがって地すべり斜面の判読，危険度の推定においては，これら構成士塊の性状を基に地すべりを型分類し，地 すべり斜面のそれぞれの型に㨟ける特徵を明らがした上で実施することが必要である。今回は，構成土塊の性質 を延展性 (ducti i ity) の概念で三つの型に分類し，統計的手法等によりそれぞれの型に淤るる地形的特改の違いを 明らかにし、その結果を利用し, 地すべり斜面の判読の難易, その危険の推定について考察及び解析手法を確立し よらとするものである。

\section{徳島県正夫地すべり地における地震探査}

「地すべり」Vol. 15，No.4（通巻 第56号）1979年（昭和54年）3月

小林 芳正, 未峯 章, 小西 利史

徳島県井川町正夫地すべり地 (三汲川帯) で行なわれた地震探査について述べている。調査方法として, 普通の 測線探查 (profile shooting) のほか, 一部の測線で扇射法 (fan shooting) を行なった。また, 一部の解析で遅れ 時間法 (delay-time merhod) を啇用した。探查の結果, $0.5 \sim 0.7 \mathrm{~km} / \mathrm{s}$ の第一層, $2.0 \sim 2.5 \mathrm{~km} / \mathrm{s}$ の第二層, $3.0 \sim$ $3.5 \mathrm{~km} / \mathrm{s}$ の第三層の速度分帯が行なわれた。第一層は厚さ $5 \sim 10 \mathrm{~m}$ で表土および崩積層, 第二層は $20 \sim 30 \mathrm{~m}$ で原 位置風化岩, 第三層は新鮮岩に対応すると推定された。縦断方向の長測線探查および斜面中段を横断する測線での 扇射法によって，地すべり地中央の基岩中に斜面最急勾配の方向をるった小断層らしい低速帯が見出された。

\section{地すべり地内における地下水区分の一手法}

「地すべり」Vol. 15. No.4（通巻 第56号）1979年（昭和54年）3月

長漊忍

地すべりの地下水質分析は，地すべり対策法の1つである地下水排除工を効果的に行ならことを目的としたもの である。この目的に照らした，分析項目の取捨選択及び地下水系の区分方法について考察した結果，分析項目は最 小限 $\mathrm{Ca}^{++}, \mathrm{Mg}^{++}$, アルカリ度の 3 項目, 水系区分には $\mathrm{Ca}^{++}+\mathrm{Mg}^{++}$ーフルカリ度の相関因から可能であり, 従来 地すべり地の地下水の水質が特異であることが強調される傾向にあったが，上記の相関図からは一般の陸水の性質 との間に異なった点は見いだせなかったことから地すべり地の地下水も一般の陸水として 対好してるいのではない かと思ら。 